PHILOSOPHY

\title{
ПУБЛІКАЦІЙНА АКТИВНІСТЬ НАУКОВО- ПЕДАГОГІЧНИХ ПРАЦІВНИКІВ В МІЖНАРОДНИХ НАУКОМЕТРИЧНИХ БАЗАХ ДАНИХ
}

\author{
Тетяна Гуменюк, доктор філософських наук, професор, Київський начіональний університет \\ культури і мистецтв, Київ, Украӥна \\ DOI: https://doi.org/10.31435/rsglobal_conf/25012021/7361
}

\begin{abstract}
In Ukraine, the scientific sphere of activity is being reformed due to new requirements for its development, in particular, national scientific journals are being prepared for inclusion in the international databases Scopus and Web of Science. Modern higher education institutions are the subject of scientometric assessments in various national and world rankings, which reflect, in particular, the level of their research activities. Now it is one of the most authoritative indicators of academic work. Today, higher education institutions of Ukraine in national and world rankings are evaluated not only by indicators of their academic and international activities, the quality of professional training of students, the results of inventive activity, but also by the level of publishing activity of researchers in journals indexed in international scientometric databases, by the number of citations of their works by other scientists.
\end{abstract}

Keywords: scientometrics, international scientometric databases, publication activity, Scopus, Web of Science.

Вступ. Актуальність теми зумовлена тим, що в наш час замість традиційних критеріїв оцінювання результатів наукової діяльності (захист дисертації, монографії, статті, їх рецензування) запроваджуються наукометричні методи. У зв'язку з цим значного поширення набуло поняття публікаційної активності, як результату науково-дослідницької діяльності науковців і науковопедагогічних працівників. Ідеться передусім про наукові публікації в міжнародних наукометричних базах даних, єдино визнаних в сучасному науковому світі. Про рівень і значення цих публікацій свідчать позиції у світових рейтингах: QS World University Rankings, The Times Higher Education World University Rankings тa Academic Rankings of World Universities.

Міністерство освіти та науки України надало провідним закладам вищої освіти можливість безкоштовного доступу до найпопулярніших наукометричних баз даних, зокрема Scopus, Web of Science (Про затвердження Порядку, 2020). Це дає змогу українським вченим актуалізувати міжнародний досвід, публікувати у цих виданнях результати своїх наукових досліджень. Крім того, сьогодні в Україні головним напрямом діяльності з інформаційно-цифрового супроводу наукових досліджень та поширення їх результатів у міжнародній системі загальної наукової комунікації стає підготовка українських наукових фахових періодичних видань до включення їх в найпопулярніші наукометричні бази даних. Участь українських вчених у міжнародних конференціях, симпозіумах, створення спільних наукових підприємств, міжнародних програм обміну, організація і проведення наукових заходів- це основні форми міжнародної співпраці, завдяки якій Україна стає повноправним учасником світового наукового товариства.

Мета статті - розкрити сутність процесів реформування наукової сфери діяльності в Україні, зумовлених новими вимогами до іiі розвитку, зокрема підготовки національних наукових журналів до внесення їх в міжнародні бази даних Scopus i Web of Science, найбільш авторитетних показників академічної роботи працівників наукових інституцій і вищих навчальних закладів.

Українським фахівцям належать вагомі теоретичні праці у сфері наукометрії. Ще у 60-ті роки XX століття засновник Центру досліджень науково-технічного потенціалу та історії науки НАН України Г. Доброва видав свою фундаментальну працю «Наука про науку: Вступ до загального наукознавства» (1966), у якій розкрив тенденції і перспективи розвитку науки в Україні. У наш час потужним імпульсом до поширення бібліометрії й наукометрії вважають появу на ринку інформаційної індустрії мультидисциплінарних баз даних Web of Science корпорації Clarivate Analytics та Scopus корпорації Elsevier. 
Результати дискусії. Протягом багатьох років дані Web of Science $\epsilon$ основним джерелом для бібліографічного аналізу. Однак з появою Google Scholar (2004 випуск бетаверсії ), а згодом і Scopus (2004) залучають різні джерела для перевірки достовірності і походження інформації. Зауважимо, що Google Scholar- це платформа, завдяки якій здійснюється відбір та індексація публікацій, а користувачам, на відміну від комерційних баз даних Web of Science i Scopus, надається безкоштовний доступ.

Наукометрична база даних Scopus - одна 3 найбільших у світі, у ній індексовані найкращі наукові журнали в галузі технічних, природничих, соціальних, медичних i гуманітарних наук. У Scopus індексуються майже 24000 наукових журналів з різних галузей науки, матеріали конференцій, книжкові видання, майже $80 \%$ яких містять анотації. Дані Scopus, окрім іншого, використовуються у визначенні деяких рейтингів провідних університетів світу, зокрема в Times Higher Education aбo QS World University Rankings.

Пошукова платформа Web of Science містить реферативні бази публікацій в наукових періодичних виданнях переважно з природничих, точних і суспільних наук. Web of Science охоплює інформацію з усіх галузей знань, індексуючи понад 12000 журналів, 120000 різних наукових матеріалів конференцій. Експерти 3 оцінювання ефективності наукових праць спираються здебільшого на дані WoS (Scopus та Web of Science, 2020). Web of Science Group i компанія Clarivate Analytics збирають наукову інформацію у всьому світі для науковців, компаній, видавців, сприяючи процесу наукових досліджень.

Web of Science - це найбільша у світі видавничо-нейтральна база наукового цитування i дослідницька аналітична платформа, в якій 1981 року було проіндексовано майже 500000 наукових публікацій із 6800 журналів. 2019 року року їх кількість зросла до 2,5 млн. публікацій iз 21300 журналів. Безперечно, це одне 3 найбільш авторитетних джерел даних широкого спектра аналітичних завдань.

Серед багатьох відомих брендів компанії- Converis, EndNote, Kopernio, Publons, ScholarOne та Інститут наукової інформації (ISI). «Університет» Web of Science Group, ISI підтримує корпус знань, що становлять основу цієї бази даних, а також пов'язаний з нею інформаційний і аналітичний контент і послуги. Ці знання поширюються завдяки проведенню конференцій, досліджень, здійснюваних для підтримки, розширення і вдосконалення бази даних. B ISI постійно оновлюють чинні стандарти, співпрацюючи з партнерами 3 державного і приватного секторів над збиранням даних публікацій і цитування, а також над створенням інноваційних індикаторів цінності для дослідників і керівників наукових установ.

Матеріали міжнародного науково-дослідницького звіту («Цінність наукометричних баз даних: від пошуку інформації до глибокої аналітики») переконує, що Web of Science $\epsilon$ основним джерелом даних про публікації й цитування, найбільш авторитетним, порівняно 3 будь-яким іншим джерелом. Ці дані вміщуються в більшості систематичних оглядів щодо наукових досліджень 3 широкого кола дисциплін, і майже вдвічі більше 3 питань організації й оцінювання наукових праць.

Основними бенефіціантами структурованого використання бібліографічних записів Web of Science $\epsilon$ біолого-медичні науковці, які системно й регулярно використовують вихідні дані, аналізуючи поточний стан дослідження тем, що мають вирішальне значення для збереження здоров'я людини і боротьби з хворобами. Завдяки цьому можливо визначати нові й перспективні наукові галузі, напрями їх фінансування. Маючи чітке уявлення про те, хто найбільш активно публікується в певній галузі, можна виявити розподіл експертного знання за країнами й організаціями, що також сприятиме об'єктивному оцінюванню їхніх наукових досягнень і перспектив.

Обсяг контенту в Scopus вже на третину більший, ніж у WoS, за цим критерієм база даних Scopus утримує першість щодо природничих, соціальних, гуманітарних наук і медицини. Кількість журналів у Scopus поповнюється швидше, ніж у WoS, однак остання переважає за обсягом архіву і за ретельністю добору журналів, за вагомістю журнальних індексів.

Для кожного вченого наукометричні бази даних становлять джерело цінної інформації для пошуку, створення чи доповнення його праць. На базі даних Scopus i WoS постійно створюються рейтинги як світового масштабу, так і на рівні певної держави, вони характеризують діяльність науковців, наукового закладу, певної наукової галузі в країні і вимірюються за індексом Гірша. Як відомо, це один 3 головних наукометричних показників у сфері науки й наукометрії, його увів в 
науковий обіг фізик Хорхе Гірш для оцінювання наукової діяльності вчених-фізиків. Згодом цей критерій почали застосовувати, оцінюючи досягнення вчених і в інших наукових галузях. Чим більше публікацій має вчений, чим більше його праці цитують інші дослідники, тим вищий h-index. Він свідчить про ефективність дослідницької діяльності і кар'єрне зростання, просування у державних і світових рейтингах, про науковий авторитет вченого.

Для підвищення рівня цитування необхідно: налагоджувати і підтримувати творчі зв'язки $з$ колегами у певній сфері досліджень, співпрацювати з іншими вченими, особливо на початку дослідницької діяльність; частіше публікувати унікальні наукові статті, особливо в міжнародних рейтингових журналах, які індексуються в Scopus та Web of Science, щоб у науковому співтоваристві на них звернули увагу; просувати своє дослідження, вдаватись до самоцитування (не більше $12 \%$ у статті), додавати результати експерименту до особистого профілю, адже це може допомогти знайти статтю у співавторстві; повідомляти зарубіжним колегам про публікацію своїх статей.

Бази даних Scopus i WoS надають користувачам можливість налаштувати профіль, використовувати переваги кожної з них. Зокрема, у WoS зручна функція пошуку за цитованим посиланням (CRS), а також функція «Пов’язані дописи», що надає інформацію про авторів, які посилалися на ті ж матеріали. Scopus також містить функції пошуку за ключовими словами чи авторами, «аналізатор журналів» - оцінювання видання за кількістю цитувань і опублікованих статей. Щоправда, певні незручності становить відсутність посилань до 1996 року.

Відстеження та аналіз цитування має важливе значення для оцінювання впливу й авторитетності кожного запису у певний період часу. Цей процес відбувається завдяки Scopus i WoS Citation Tracker, він відображає кількісний рівень цитувань певної публікації в інших дослідженнях, надає змогу виявляти ефект зацікавленості й актуальності (Scopus та Web of Science, 2020).

Кожен сучасний вищий навчальний заклад є суб'єктом наукометричних оцінювань багатьох у національних і світових рейтингах, які відбивають рівень його науково-дослідницької діяльності. Тепер це один 3 найбільш авторитетних показників академічної роботи наукових працівників, що характеризує їх публікаційну активність в журналах, індексованих в міжнародних наукометричних базах даних (Scopus, Web of Science тощо) і кількість цитувань їхніх праць іншими вченими. Рейтинг наукової установи залежить від наукової активності кожного працівника, а це впливає на її зовнішнє фінансування (Атестація, 2019).

Заклади освіти і науки, відповідно до вимог часу, обирають нові напрями реформування і розвитку наукової роботи. Міністерство освіти і науки України здійснює атестацію наукових напрямів у закладах вищої освіти за спеціальною методикою, завдяки якій визначається ефективність наукової діяльності науково-педагогічних працівників протягом останніх п’яти років. За умови найвищої характеристики, такі наукові установи отримають фінансування спочатку в обсязі 100 млн. грн. Оцінювання здійснюють експерти, провідні спеціалісти відповідних галузей знань за такими показниками: перспективність ідей, чільні місця наукових досягнень у світових рейтингах; практична цінність дослідницьких результатів (застосування їх іншими науковцями, економічна й екологічна ефективність тощо); сприяння вирішенню глобальних питань; інтегрування у світовий науковий простір.

Експертне рішення затверджує атестаційна комісія, за результатами цієї атестації вищі навчальні заклади будуть розподілені на чотири групи: А, Б, В та не атестовані. Фінансування отримають передусім вищі навчальні заклади групи $\mathbf{A}$, з часом передбачається фінансування й закладів групи Б.

Досі заклади вищої освіти фінансувались з бюджету лише для конкретного проєкту, що не давало можливості планувати тривалі перспективні дослідження, у новій ситуації зростає мотивація до системних новітніх експериментів, тому для українських вчених $\epsilon$ перспектива посісти вищі рівні в різних рейтингах. Слід визнати, що наука, як рушійна сила цивілізаційного процесу, зазнає впливу соціальних і політичних змін у світі. Багато країн вже підвищили свій науковий рейтинг завдяки міжнародній співпраці, Україна також бере участь, адже потенціал українських вчених відомий у світі. Для поширення їх досягнень необхідно долучитись до міжнародних наукометричних баз даних, як системи загальних наукових комунікацій.

На порталі «Times Higher Education World University Rankings 2020» було опубліковано світовий рейтинг університетів, визначений за даними Scopus (Elsevier), - тільки шість українських закладів вищої освіти посіли в ньому відповідні позиції в межах 801-1000, зокрема: Національний 
університет «Львівська політехніка», Львівський національний університет імені Івана Франка, Національний технічний університет «Харківський політехнічний інститут», Сумський державний університет, Київський національний університет імені Тараса Шевченка, Харківський національний університет імені Василя Каразіна (Українські ВНЗ, 2019).

Рейтинг визначались за такими критеріями ефективності (\%):

1. Research - дослідження: $30 \%$ (обсяг, дохід, репутація); опитування репутації (18\%), дохід від досліджень (6\%), продуктивність дослідження (6\%);

2. Teaching - викладання: $30 \%$ (освітнє середовище); опитування репутації (15\%), співвідношення кількості персоналу і студентів (4.5\%), докторів і бакалаврів $(2.25 \%)$, докторантів та академічного складу (6\%), інституційний дохід (2.25\%);

3. International outlook - міжнародні перспективи: 7.5\% (персонал, студенти, дослідження), іноземні студенти (2.5\%), міжнародний персонал (2.5\%), міжнародне співробітництво (2.5\%);

4. Citations - цитування: 30\% (дослідницький вплив); моніторинг університетських публікацій та середньої кількості їх цитування для виявлення найбільш актуальних наукових у науковому співтоваристві;

5. Industry income - дохід галузі: 2.5\% (передання знань); здатність закладів вищої освіти передавати інноваційну інформацію для підприємств.

Цей рейтинг складений на сайті Освіта.иа на основі моніторингу суб'єктів наукововидавничої діяльності України за показниками бази даних SciVerse Scopus. Результати рейтингу вищих навчальних закладів, за показниками бази даних Scopus, відбивають рівень цитування наукових публікацій співробітниками навчального закладу.

У рейтинговій таблиці вищі навчальні заклади України ранжовані і за індексом Гірша. За даними рейтингу 2020 року, найвищий індекс Гірша серед університетів України мають Київський національний університет імені Тараса Шевченка - 93 (89 у рейтингу 2019 року), Харківський національний університет імені Василя Каразіна- 73 (70) та Львівський національний університет імені Івана Франка 64 (60) (Рейтинг університетів, 2020 ).

Центр міжнародних проєктів «Євроосвіта» (http://www.euroosvita.net/) у партнерстві 3 міжнародною групою експертів IREG Observatory on Academic Ranking and Excellence (http://ireg-observatory.org/en/) презентували академічний рейтинг закладів вищої освіти України III, IV рівнів акредитації «Топ-200 Україна 2019» (Линовицька О., 2020). Згідно з методикою проєкту «Топ-200 Україна», розробленою відповідно до Берлінських принципів ранжування університетів, за основу взято відкриті дані прямих вимірів (сумарно 85\%) та експертні висновки фахівців в галузі вищої освіти і головних ринків праці України (сумарно 15\%). Відповідно до цієї методики, діяльність закладів вищої освіти (закладів вищої освіти) оцінюеться за інтегрованим індексом - Із. Цей індекс містить три комплексні складники: Із = Інп $(40 \%)+$ Ін $(25 \%)+$ Імв (20\%), де Інп - це індекси якості науково-педагогічного потенціалу, Ін - індекс якості навчання, Імв - індекс міжнародного визнання.

Для формування зазначених індексів застосовано 30 індикаторів прямого вимірювання (анкетні дані, інформація на сайтах закладів вищої освіти, дані міжнародних асоціацій університетів, дані про участь ЗВО в міжнародних проєктах (Horizon 2020, Erasmus+), інформація про участь закладів вищої освіти в міжнародних рейтингах (Webometrics, Scopus, uniRank), дані МОН України, СДЕБО, Комітету з питань державних премій України і премій імені Т. Г. Шевченка, участь закладів вищої освіти у проєктах, фінансованих NATO в рамках Програми «Наука заради миру і безпеки», а також у білатеральних проєктах, середній конкурсний бал вступника та інші відкриті дані.

Експертне оцінювання якості науково-педагогічного потенціалу і якості навчання (сумарно 15\%) здійснювалось за такими критеріями: рівень базової, загальноосвітньої підготовки студентів, рівень фахової підготовки, рівень практичного володіння інформаційними технологіями, попит на випускників закладів вищої освіти на ринку праці.

Одну $з$ головних тенденцій у цьому ранжуванні університетів становив баланс між створенням нових критичних знань, результатів досліджень та інновацій і практичним використанням цих напрацювань в сучасному суспільстві. За даними експертів, які брали участь у підготовці цього рейтингу, переважає майже незмінна тенденція: значний розрив між потребами ринків праці в Україні і результатами роботи університетів за моделлю сучасних знань, головними компетенціями і якістю практичної підготовки фахівців. 
Кращими визнані Київський національний університет імені Тараса Шевченка, Національний технічний університет України «Київський політехнічний інститут імені Ігоря Сікорського», Харківський національний університет імені Василя Каразіна (Линовицька О., 2020).

За таким же зразком, на основі сучасних тенденцій розвитку університетів, узагальнених міжнародною Конференцією IREG (IREG 2019 Conference, Bologna, Italy, 8-10 травня 2019 року) і Берлінських принципів, затверджених учасниками другої наради IREG (Берлін, Німеччина, 18-20 травня 2006 року) презентовано й наступний, чотирнадцятий академічний рейтинг закладів вищої освіти України.

Надалі базові рейтинги університетів України будуть визначати лише за відкритими даними прямих вимірів на основі вебресурсів незалежних національних і міжнародних організацій і установ. Жодні матеріали чи експертні оцінювання самих університетів і органів управління не актуальні. Зокрема, рейтинг українських університетів 2020 року розраховували за десятьма показниками, шість із них - міжнародні, чотири - національні:

1. QS World University Rankings - 0.135: академічна діяльність (https://www.topuniversities.com);

2. Scopus - 0.135: науково-видавнича діяльність (http://ru.osvita.ua);

3. Webometrics - 0.135: оцінювання науково-дослідних досягнень університетів шляхом порівняння їх інтернет-сайтів (http://webometrics.info);

4. Участь у програмах Erasmus + Європейського Союзу- 0.135: міжнародна діяльність (https://erasmusplus.org.ua/erasmus/novyny-i-baza-proektiv.html);

5. Google Scholar Citations - 0.135: цитування наукових праць вчених університету (http://www.webometrics.info/en/transparent);

6. UniRank -0.10 : якість представлення і популярність закладу вищої освіти в інтернетпросторі на основі незалежних вебометричних показників (https://www.4icu.org/ua/);

7. Результати всеукраїнських студентських олімпіад i конкурсів наукових робіт 2018/2019 (за сумою балів) - 0.065: якість підготовки (https://imzo.gov.ua/2019/08/07/nakaz-monvid-5-08-2019-1060, https://imzo.gov.ua/2019/08/07/nakaz-mon-vid-05-08-2019-1059);

8. Стипендії Президента України та Кабінету Міністрів України для молодих вчених 0.065: навчально-наукова робота (http://www.kdpu-nt.gov.ua);

9. Кількість патентів, отриманих вченими університету протягом 2019 року -0.065 : винахідницька діяльність (http://www.euroosvita.net, https://ukrpatent.org);

10.Середнє зважене значення для рейтингів закладів вищої освіти за кількістю заяв, поданих абітурієнтами та середнім конкурсним балом в 2019 році- 0.03: привабливість університету для абітурієнтів (https://vstup2019.edbo.gov.ua/statistics/).

Крім рейтингів, привертає увагу й громадське обговорення нового проєкту «Порядку присудження наукових ступенів», розробленого в Національному агентстві із забезпечення якості вищої освіти. У ньому конкретизовано вимоги щодо присудження ступенів доктора філософії і доктора наук. Зокрема, здобувач наукового ступеня доктора наук має опублікувати не менше трьох статей, а 31 вересня 2022 року - не менше п'яти статей з наукового напряму дисертаційного дослідження, щонайменше, у двох різних періодичних виданнях, включених до «Переліку наукових фахових видань України» категорії «А» або в зарубіжних виданнях, проіндексованих в базах даних Web of Science Core Collection та/або Scopus.

Висновки. Підсумовуючи, зазначимо, що наукометричні оцінювання сучасних закладів вищої України як суб’єктів національних і світових рейтингів, здійснюються, окрім академічної та міжнародної діяльності, якості підготовки студентів, винахідницької діяльності, ще й за рівнем публікаційної активності науково-педагогічних працівників у журналах, індексованих в міжнародних наукометричних базах даних (Scopus, Web of Science тощо) та за кількістю цитувань їхніх праць іншими вченими.

В Україні здійснюється реформування наукової сфери діяльності, зумовлене новими тенденціями щодо організації наукової діяльності і зростання ії ефективності, зокрема й новими вимогами до наукових публікацій у міжнародних наукових виданнях, проіндексованих в наукометричних базах даних. Це спонукає наукові установи і заклади вищої освіти дбати, щоб національні наукові журнали були визнані в міжнародних базах даних Scopus тa Web of Science, розвивати наукометрію, сприяти публікаційній діяльності науково-педагогічних працівників. Це важлива умова для налагодження міжнародних наукових контактів і кар'єрного зростання науковців, підвищення ефективності наукових досліджень. 


\section{REFERENCES}

1. Certification of scientific directions for their financing in Ukrainian universities. (2019). [Atestacija naukovykh naprjamiv dlja jikhnjogho finansuvannja v ukrajinsjkykh VNZ.] In: Science and metrics. Vip. 2. pp. 4-5. [in Ukrainian].

2. Lynovytska O. Labor market inquiries: a challenge for Ukrainian universities. [Zapyty rynku praci: vyklyk dlja ukrajinsjkykh universytetiv]. [Jelektronnyj resurs] // Rezhim dostupu: URL: http://euroosvita.net/index.php/?category=1\&id=6091 (date of application: 03.08.2020). [in Ukrainian].

3. About the statement of the Order of maintenance of access of establishments of higher education and scientific establishments to electronic scientific databases: the Order of the Ministry of Education and Science [Pro zatverdzhennja Porjadku zabezpechennja dostupu zakladiv vyshhoji osvity i naukovykh ustanov do elektronnykh naukovykh baz danykh: Nakaz Ministerstva osvity i nauky]. Vol. 269, 27.02.2019. [Jelektronnyj resurs] // Rezhim dostupu: URL: https://zakon.rada.gov.ua/laws/show/z046319\#Text (date of application: 18.09.2020). [in Ukrainian].

4. Ranking of universities according to Scopus 2020. [Rejtyngh universytetiv za pokaznykamy Scopus 2020 roku]. [Jelektronnyj resurs] // Rezhim dostupu: URL: http://osvita.ua/vnz/rating/72780/ (date of application: 17.08.2020). [in Ukrainian].

5. Ukrainian universities in the struggle for ratings. (2019). [Ukrajinsjki VNZ u borotjbi za rejtynghy]. In: Science and metrics. [Nauka i metryka]. Vol. 2. P. 27.

6. Scopus and Web of Science: parallels and points of intersection. (2020). [Scopus ta Web of Science: paraleli ta tochky peretynu]. In: Science and metrics. [Nauka i metryka]. Vol. 3. pp. 8-10. [in Ukrainian]. 